\title{
Knowledge of Healthcare Professionals Regarding Hepatitis B in Rania Hospitals
}

\author{
Zhino Raouf Ali \\ Health Development and Training Center \\ Directorate of Health- Slemani Administration \\ Ministry of Health \\ Slemani, Iraq \\ zhino.hdtc@gmail.com
Khalid Muhamad Hamad
Nursing Department
College of Nursing
University of Raparin
Rania, Iraq
xalidmuhamad58@gmail.com

\author{
Mohammed Rasol Ahmed \\ Nursing Department \\ College of Nursing \\ University of Raparin \\ Rania, Iraq \\ mohammed.ns7090@uor.edu.krd \\ Zhiar Hussen Wsu \\ Nursing Department \\ College of Nursing \\ University of Raparin \\ Rania, Iraq \\ zhiarhussen99@gmail.com
}

\begin{tabular}{l} 
Article Info \\
\hline Volume 5 - Special Issue: $4^{\text {th }}$ \\
International Conference on the Health \\
and Medical Science : Medical \\
Researches Improve Life Quality \\
(ICHMS 2020) \\
DOI: \\
10.24017/science.2020.ICHMS2020.20 \\
Article history: \\
Received: 27 September 2020 \\
Accepted: 04 October 2020 \\
\hline
\end{tabular}

Keywords:

Knowledge, Hepatitis B virus, health care professionals, Rania hospitals, Kurdistan region of Iraq

\begin{abstract}
Hepatitis B virus (HBV) infection is a major public health problem worldwide especially for healthcare professionals (HCPs). It is a potentially lifethreatening condition because leads to liver infection, and liver cancer. There is a shortage of research on undergraduate students. The main aim of this study was conducted to assess the level of knowledge of health care professionals regarding $H B V$ at Rania hospitals in the Kurdistan region of Iraq during the period of 20th October 2019 to $16^{\text {th }}$ April 2020. Non-probability purposive sample of (303) HCPs; for data collection, the study instrument was constructed and designed through reading literature, books, and articles which included (42) items. Reliability of the instrument was determined through the use of stability reliability (test and retest) approach which was estimated as $r=(0.83$.)The data were collected through the use of the interview technique then organized and coded into computer files. Statistical approaches were uses for data analysis, which includes: descriptive and inferential statistics and chi-square, data analysis (SPSS version 25). The results indicated that the majority of the study samples were in the age group $(\leq 30))$ years and the female participants was more than male, threequarters of the participants were married, most of them were graduated from institute nursing and
\end{abstract}


less than half of HCPs had 6-10 years of employment, but the majority of the participants were not trained at all, and most of them had not immunized against $\mathrm{HBV}$ vaccine. Three-quarters of $\mathrm{HCP}$ s had moderate knowledge regarding $\mathrm{HBV}$ infection. Also, the current study demonstrated a significant association between the educational level and HCP's knowledge regarding $\mathrm{HBV}$, at a $\mathrm{P}$ value less than 0.05. On the other hand, there was no significant association between HCP's age, gender, marital status, years of employment, and training course concerning hepatitis with the level of knowledge regarding $\mathrm{HBV}$. The researchers recommended to the ministry of health and directorate of health in Rania city to complete vaccinate against $\mathrm{HBV}$ for all HCPs and participating their staff in healthy scientific issues and symposiums.

Copyright (C) 2020 Kurdistan Journal of Applied Research. All rights reserved.

\section{INTRODUCTION}

Hepatitis B is a viral infection and is one of the very serious infections that can cause both acute and chronic diseases [1]. According to a 2020 World Health Organization As of 2016, 27 million people (10.5\%) of all people estimated to be living with hepatitis B) were aware of their infection, while 4.5 million (16.7\%) of the people diagnosed were on treatment [2]. Hepatitis B virus infection primarily affects the liver. Typically the incubation period for hepatitis B in 90 days (range, 60- 150 days). Newly acquired acute HBV infections only cause symptoms some of the time. The presence of signs and symptoms varies by age. Most children under age 5 years and generally asymptomatic, whereas $30 \%-50 \%$ of people aged $\geq 5$ years have signs and symptoms of acute infection include malaise, fatigue, poor appetite, nausea, vomiting, abdominal pain, fever, dark urine, light color(clay-colored) stool, joint pain, and jaundice. Hepatitis B virus transmission can take place through exposure to infectious blood, semen, and other body fluids. This is termed horizontal transmission. Infected mothers can transmit to infants at the time of birth or an infected family member to an infant in early childhood. This is termed perinatal transmission (sometimes also called vertical transmission). Transfusions of HBV- contaminated blood and blood products and contaminated injections during medical procedures may also be responsible for HBV transmission [3]. The standard precautions can take as measures to prevent the spread of infection and to reduce transmission of micro-organisms to other patients or HCPs. Standard precautions include the use of personal protective equipment (PPE) when performing certain tasks. PPE consists of garments and apparel that protect the health care professional from contracting a disease from a resident. Standard precautions are used anytime the HCPs anticipate contact with blood or any moist body fluid( except sweat), secretions, or excretions and also used anytime will have mucous membrane contact [6]. HCPs are closely related to the patient's blood or body fluid due to occupational exposure. They are likely to sustain non-sterile exposures either in the form of needle-sticks, sharps-related injuries, or splashes of body fluids to eyes and mucus membranes. If one sustains a needle stick and the source (patient) is an infected one, the risk of transmission of HIV, HBV, and $\mathrm{HCV}$ per exposure is $0.3 \%, 37-62 \%$, and $1.8 \%$ per exposure respectively[5]. Each year it is predestined that about 66,000 of HCPs globally Sharps-related injuries cause HBV [6]. Throughout the world, a safe and effective vaccine 
against $\mathrm{HBV}$ is available but one of the reasons for not vaccinated against HBV is the resource-poor countries and maybe lack of knowledge regarding the vaccine [7].

\section{METHODS AND MATERIALS}

A non-probability, purposive sample of (303) healthcare professionals, male and female. Had been executed to assess the level of HCPs knowledge towards hepatitis B at Rania Hospitals (Chwarqurna Hospital, Rania Pediatric and Maternity Hospital, Raparin Health Center in Rania District, Shahid Ahmad Ismail Hospital, Rania Teaching Hospital, Dialysis Center, and Rania Dental Center) from the period of $20^{\text {th }}$ of October 2019 up to $16^{\text {th }}$ of April 2020. The written official, consent was obtained from the College of the Nursing/ University of Raparin, and Rania Directorate of Health to perform the study at the Rania Hospitals. The data were collected through the utilization of the constructed tool; interview techniques were entered and analyzed with a statistical package for social sciences version 25 software.

The Content Validity of the tool resolve through a panel of (5) specialists with average years of expertise of 13.6 years, in various fields of science (Nursing, and Medicine) to explore the clarity, relevancy, and adequacy of the items of the instrument. A pilot study is applied to (20) male and female HCPs, during the period of $8^{\text {th }}$ of January 2020 to $22^{\text {th }}$ of January 2020. Reliability of the sheet was determined through the use of items, stability (test and re-test) approach; using pretest for the (20) HCPs to assess the level of knowledge regarding hepatitis B and after two week's applied the same questionnaire for the same HCPs to assess the level of knowledge. The items rated and scored according to the following patterns: Three-point type Likert Scale is used for rating the items as Yes, No, and I don't know. Is scored as (2) for Yes, (1) for I don't know, and (0) for No for positive questions, but negative questions are scored as (0) for Yes and (2) for No and (1) for I don't know.

\section{RESULTS}

(Table 1) showed $(\leq 30)$ that the highest age of the participants, $(50.5 \%)$ of them were female, $(64.0 \%)$ were graduated from Institute, $(31.4 \%)$ of them were Years of Employment between $(6-10),(86.8 \%)$ were not trained concerning hepatitis, $(63.0 \%)$ of them were completely vaccinated, $(65.3 \%)$ were believed that the doses of hepatitis B vaccines they needed for complete protection were (3) doses.

Table 1: Socio-demographic Descriptive $(\mathrm{n}=303)$

\begin{tabular}{|c|c|c|c|}
\hline Variables & Categories & No. & $(\%)$ \\
\hline \multirow[t]{4}{*}{ Age (Years) } & $\leq 30$ & 87 & 28.7 \\
\hline & $31-35$ & 63 & 20.8 \\
\hline & $36-40$ & 72 & 23.8 \\
\hline & $\geq 41$ & 81 & 26.7 \\
\hline \multirow[t]{2}{*}{ Gender } & Male & 150 & 49.5 \\
\hline & Female & 153 & 50.5 \\
\hline \multirow[t]{3}{*}{ Marital Status } & Single & 73 & 24.1 \\
\hline & Married & 225 & 74.3 \\
\hline & Divorced & 5 & 1.7 \\
\hline \multirow{3}{*}{$\begin{array}{c}\text { Educational } \\
\text { Level }\end{array}$} & Intermediate School & 7 & 2.3 \\
\hline & Secondary School & 28 & 9.2 \\
\hline & Institute Graduate & 194 & 64.0 \\
\hline
\end{tabular}




\begin{tabular}{|c|c|c|c|}
\hline & College and postgraduate & 74 & 24.4 \\
\hline \multirow{4}{*}{$\begin{array}{c}\text { Years of } \\
\text { Employment }\end{array}$} & $\leq 5$ & 62 & 20.5 \\
\hline & $6-10$ & 95 & 31.4 \\
\hline & $11-15$ & 56 & 18.5 \\
\hline & $\geq 16$ & 90 & 29.7 \\
\hline \multirow{2}{*}{$\begin{array}{c}\text { Did you train } \\
\text { concerning } \\
\text { hepatitis? }\end{array}$} & Yes & 40 & 13.2 \\
\hline & No & 263 & 86.8 \\
\hline \multirow[t]{2}{*}{$\begin{array}{l}\text { Completely } \\
\text { vaccinated? }\end{array}$} & Yes & 191 & 63.0 \\
\hline & No & 112 & 37.0 \\
\hline \multirow{6}{*}{$\begin{array}{c}\text { How many doses } \\
\text { of hepatitis B } \\
\text { vaccines needed } \\
\text { for complete } \\
\text { protection? }\end{array}$} & 1 & 2 & 0.7 \\
\hline & 2 & 6 & 2.0 \\
\hline & 3 & 198 & 65.3 \\
\hline & 4 & 34 & 11.2 \\
\hline & 5 & 24 & 7.9 \\
\hline & I do not know & 39 & 12.9 \\
\hline
\end{tabular}

(Table 2) showed that that the severity of item $(1,2,3,6,7,8,9,10,11,12,15,16,17,18$, $19,20,23,24,29,30)$ were high and items $(4,5,13,14,21,22,25,26,27,28)$ were moderate in severity.

Table 2: Participant's response rating regarding each item

\begin{tabular}{|c|c|c|c|c|c|c|}
\hline No. & Items & Yes (\%) & No (\%) & $\begin{array}{c}\text { I Don't } \\
\text { know }\end{array}$ & MS & Severity \\
\hline 1 & $\begin{array}{c}\text { The Kidneys affected by } \\
\text { Hepatitis B infection }\end{array}$ & 199 (65.7) & $59(19.5)$ & $45(14.9)$ & 1.46 & $\mathrm{H}$ \\
\hline 2 & $\begin{array}{c}\text { Hepatitis B is a risk factor } \\
\text { for liver cancer }\end{array}$ & $228(75.2)$ & $41(13.5)$ & $34(11.2)$ & 1.62 & $\mathrm{H}$ \\
\hline 3 & $\begin{array}{l}\text { Hepatitis B affects liver } \\
\text { function }\end{array}$ & $285(94.1)$ & $7(2.3)$ & $11(3.6)$ & 1.92 & $\mathrm{H}$ \\
\hline 4 & $\begin{array}{l}\text { Hepatitis B transmitted } \\
\text { through food }\end{array}$ & $96(31.7)$ & $168(55.4)$ & 39 (12.9) & 1.24 & M \\
\hline 5 & $\begin{array}{l}\text { Hepatitis B transmitted } \\
\text { through drink }\end{array}$ & $111(36.6)$ & $154(50.8)$ & $38(12.5)$ & 1.14 & M \\
\hline 6 & $\begin{array}{c}\text { Hepatitis B transmitted } \\
\text { through blood to blood } \\
\text { contact }\end{array}$ & $296(97.7)$ & $3(1.0)$ & $4(1.3)$ & 1.97 & $\mathrm{H}$ \\
\hline 7 & $\begin{array}{l}\text { Hepatitis B transmitted } \\
\text { through unsafe sex }\end{array}$ & $261(86.1)$ & $22(7.3)$ & $20(6.6)$ & 1.79 & $\mathrm{H}$ \\
\hline 8 & $\begin{array}{l}\text { Hepatitis B transmitted } \\
\text { through tattoos }\end{array}$ & $238(78.5)$ & $26(8.6)$ & 39 (12.9) & 1.70 & $\mathrm{H}$ \\
\hline 9 & $\begin{array}{l}\text { Hepatitis B transmitted } \\
\text { through sharing needles }\end{array}$ & $294(97.0)$ & $2(.7)$ & $7(2.3)$ & 1.96 & $\mathrm{H}$ \\
\hline 10 & $\begin{array}{c}\text { Hepatitis B transmitted by } \\
\text { unsterilized surgical } \\
\text { instruments }\end{array}$ & $286(94.4)$ & $8(2.6)$ & $9(3.0)$ & 1.92 & $\mathrm{H}$ \\
\hline 11 & $\begin{array}{l}\text { Hepatitis B is transmitted } \\
\text { through infected mother to } \\
\text { infant during birth. }\end{array}$ & $258(85.1)$ & $21(6.9)$ & $24(7.9)$ & 1.78 & $\mathrm{H}$ \\
\hline
\end{tabular}

Kurdistan Journal of Applied Research $\mid 4^{\text {th }}$ International Conference on the Health and Medical Science: Medical Researches Improve Life Quality (ICHMS 2020) | 181 


\begin{tabular}{|c|c|c|c|c|c|c|}
\hline 12 & $\begin{array}{l}\text { Hepatitis B is transmitted } \\
\text { through hugging each other } \\
\text { and shaking hands with an } \\
\text { infected person. }\end{array}$ & $28(9.2)$ & $228(75.2)$ & $47(15.5)$ & 1.66 & $\mathrm{H}$ \\
\hline 13 & $\begin{array}{l}\text { Hepatitis B transmitted } \\
\text { through sneezing }\end{array}$ & $151(49.8)$ & $151(49.8)$ & $36(11.9)$ & 1.12 & $\mathrm{M}$ \\
\hline 14 & $\begin{array}{l}\text { Hepatitis B spread through } \\
\text { the air in an enclosed } \\
\text { environment }\end{array}$ & 65 (21.5) & $144(47.5)$ & $94(31.0)$ & 1.26 & M \\
\hline 15 & $\begin{array}{c}\text { Following the infection } \\
\text { control guidelines in the } \\
\text { workplace prevented } \\
\text { hepatitis B. }\end{array}$ & $266(87.8)$ & $17(5.6)$ & $20(6.6)$ & 1.82 & $\mathrm{H}$ \\
\hline 16 & $\begin{array}{l}\text { Using (Personal Protective } \\
\text { Equipment) like gloves, } \\
\text { masks, gown, and eye } \\
\text { goggle prevented Hepatitis B } \\
\text { in the hospital. }\end{array}$ & $273(90.1)$ & $17(5.6)$ & $13(4.3)$ & 1.84 & $\mathrm{H}$ \\
\hline 17 & $\begin{array}{l}\text { Recapping needles is one } \\
\text { way to transmit the hepatitis } \\
\text { B virus in the hospital. }\end{array}$ & $263(86.8)$ & $20(6.6)$ & $20(6.6)$ & 1.80 & $\mathrm{H}$ \\
\hline 18 & $\begin{array}{l}\text { Signs and symptoms of acute } \\
\text { Hepatitis B within the first } 6 \\
\text { months of exposure to it. }\end{array}$ & $175(57.8)$ & $37(12.2)$ & $91(30.0)$ & 1.46 & $\mathrm{H}$ \\
\hline 19 & $\begin{array}{l}\text { Asymptomatic cause with } \\
\text { chronic hepatitis B can } \\
\text { transmit the disease to other }\end{array}$ & 217 (71.6) & 24 (7.9) & $62(20.5)$ & 1.64 & $\mathrm{H}$ \\
\hline 20 & $\begin{array}{c}\text { Hepatitis B virus detected in } \\
\text { the blood test }\end{array}$ & $292(96.4)$ & $5(1.7)$ & $6(2.0)$ & 1.95 & $\mathrm{H}$ \\
\hline 21 & $\begin{array}{l}\text { Hepatitis B virus detected in } \\
\text { semen test }\end{array}$ & $113(37.3)$ & $93(30.7)$ & $97(32.0)$ & 1.07 & M \\
\hline 22 & $\begin{array}{c}\text { Hepatitis B virus detected in } \\
\text { a saliva test }\end{array}$ & $100(33.0)$ & $102(33.7)$ & $101(33.3)$ & 0.99 & M \\
\hline 23 & $\begin{array}{l}\text { Hemodialysis patients are at } \\
\text { risk for Hepatitis B virus }\end{array}$ & $241(79.5)$ & $23(7.6)$ & $39(12.9)$ & 1.72 & $\mathrm{H}$ \\
\hline 24 & $\begin{array}{c}\text { After all doses of } \\
\text { vaccination for hepatitis B, } \\
\text { the test for the immune } \\
\text { system is very important. }\end{array}$ & $253(83.5)$ & $15(5.0)$ & 35 (11.6) & 1.79 & $\mathrm{H}$ \\
\hline 25 & $\begin{array}{l}\text { Hepatitis B virus can survive } \\
\text { outside the body for at least } \\
7 \text { days. }\end{array}$ & $92(30.4)$ & $58(19.1)$ & $153(50.5)$ & 1.11 & M \\
\hline 26 & $\begin{array}{l}\text { During the cleaning of } \\
\text { surgical instrument the } \\
\text { hepatitis B virus kills by } \\
\text { alcohol or Iodine }\end{array}$ & $142(46.9)$ & $87(28.7)$ & $74(24.4)$ & 0.82 & M \\
\hline 27 & $\begin{array}{c}\text { The use of Hookah is one of } \\
\text { the causes of the spread of } \\
\text { hepatitis B virus }\end{array}$ & 99 (32.7) & $92(30.4)$ & $112(37.0)$ & 1.02 & M \\
\hline 28 & $\begin{array}{l}\text { Alcohol consumption is the } \\
\text { cause of getting hepatitis B. }\end{array}$ & $154(50.8)$ & $64(21.1)$ & $85(28.1)$ & 1.30 & M \\
\hline 29 & $\begin{array}{l}\text { Addiction to drug one of the } \\
\text { cause of hepatitis B }\end{array}$ & $164(54.1)$ & $43(14.2)$ & $96(31.7)$ & 1.40 & $\mathrm{H}$ \\
\hline 30 & $\begin{array}{l}\text { Hepatitis B is transmitted } \\
\text { from scissors and blade } \\
\text { razors through salon and } \\
\text { barbershops. }\end{array}$ & $256(84.5)$ & $13(4.3)$ & 34 (11.2) & 1.80 & $\mathrm{H}$ \\
\hline
\end{tabular}

Kurdistan Journal of Applied Research $\mid 4^{\text {th }}$ International Conference on the Health and Medical Science: Medical Researches Improve Life Quality (ICHMS 2020) | 182 
(Table 3$)$ showed that most (68.3\%) of the study sample had a moderate level of knowledge regarding the hepatitis $\mathrm{B}$ virus.

Table 3: Level of HCP's knowledge regarding hepatitis B

\begin{tabular}{lcc}
\hline & Frequency & Percent \\
\hline Low & 6 & 2.0 \\
\hline Moderate & 207 & 68.3 \\
\hline High & 90 & 29.7 \\
\hline Total & 303 & 100.0 \\
\hline
\end{tabular}

(Table 4) indicated that there was no significant relationship between levels of health care worker's knowledge with age, gender, marital status, years of employment, and training course concerning the hepatitis $\mathrm{B}$ virus at $\mathrm{p}$-value greater than 0.05 , except educational level at $\mathrm{p}$ value less than 0.05 .

Table 4: Relationship between of HCP's knowledge regarding hepatitis B virus and some Sociodemographic characteristics

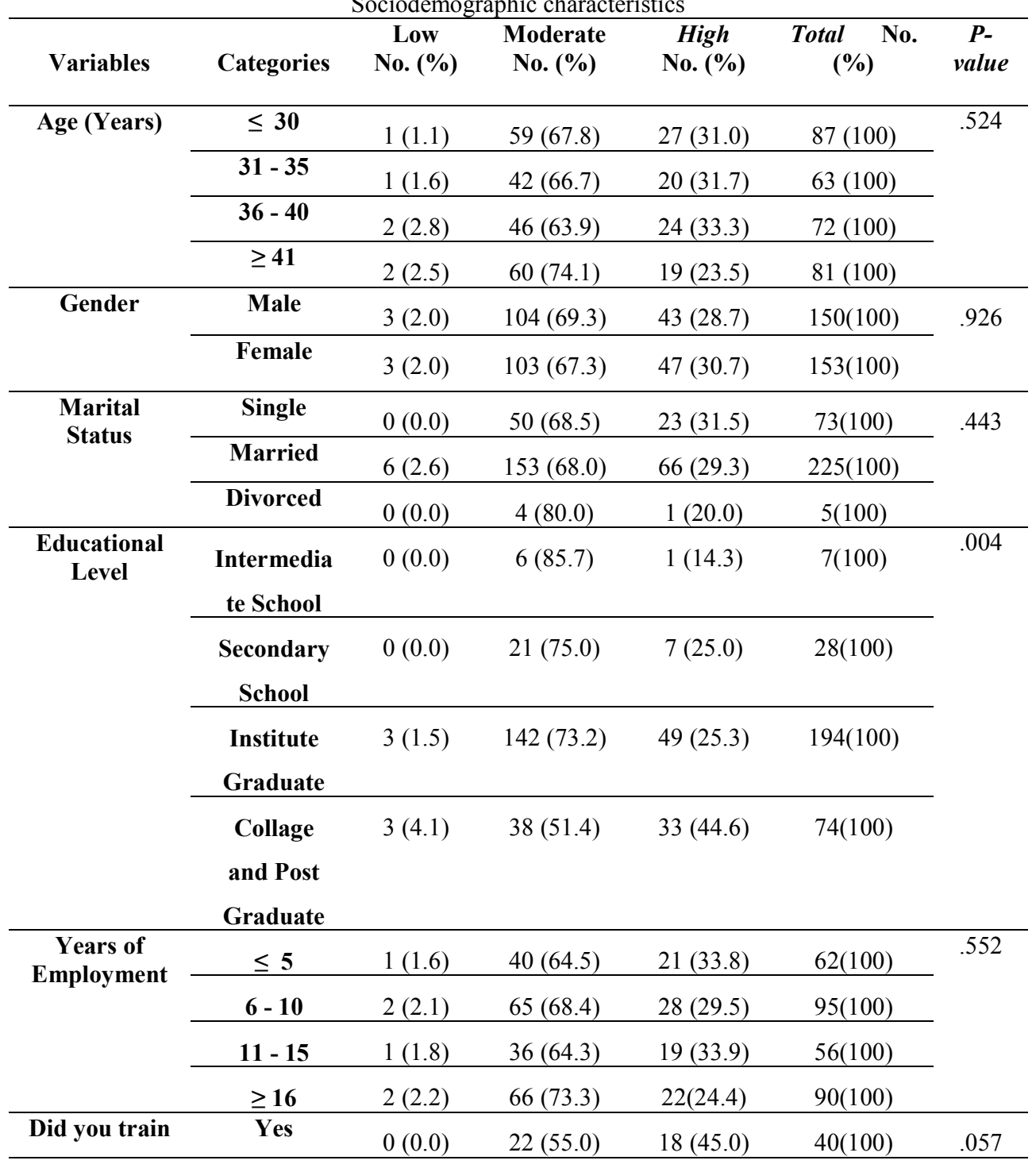

Kurdistan Journal of Applied Research $\mid 4^{\text {th }}$ International Conference on the Health and Medical Science: Medical Researches Improve Life Quality (ICHMS 2020) | 183 


\begin{tabular}{cccccc}
\hline $\begin{array}{c}\text { concerning } \\
\text { hepatitis? }\end{array}$ & No & $6(2.3)$ & $185(70.3)$ & $72(27.4)$ & $263(100)$ \\
\hline Total & & $6(2.0)$ & $207(68.3)$ & $90(29.7)$ & $303(100)$ \\
\hline
\end{tabular}

\section{DISCUSSION}

Regarding the findings of first part of the data analysis which about Socio demographic of the study participants, showed that the highest age of participants was $(\leq 30)$ years old, more than half of the study sample were female three-quarters of the study samples were married, the most of them were graduated from the institute, less than half of the HCPs are the years of employment between (6-10) years. The number of HCPs who participate in training was 40 (13.2\%). Most of the HCPs are completely vaccinated and they believe that they needed three doses of hepatitis B vaccines.The majority of the participants aware that HBV can affect kidneys, liver cancer, and liver function agree with the study was done in a district south, Karachi [8]. About more than half provided the correct answer to the HBV is not transmitted through food and drink, the present finding disagrees with another study done in Southern Nigeria [9]. The respondents demonstrated that the $(9.3 \%)$ provided the correct answer. The vaccine against hepatitis B infection has been available since 1982[10]. Hepatitis B vaccine is 95\% effective in preventing HBV infection and its long-term effects. Although vaccination rates are found to be lower among healthcare providers, their risk level is considered to be higher vaccine coverage rates [11]. In the current study, although many HCPs had a positive attitude toward hepatitis B infection and vaccination, only 191 (63\%) of participants were completely vaccinated against hepatitis $\mathrm{B}$, the result of the present study is less than another study carried out in the tertiary hospital in India were 71\% [12]. The (86.8\%) of HCPs knew that recapping needles is one way the transmitted HBV, needle stick injuries may occur when HCPs dispose of needles, collect and dispose of materials used during patient care procedures, administer injections, draw blood, or handle trash or dirty linens where needles have been inappropriately discarded [13]. The safest way to dispose of a used needle is immediately placing the needle in a sharps disposal container to reduce the risk of needle sticks, cuts, and punctures, in the present study found only $(86.8 \%)$ were aware that recapping needles is one way to transmit hepatitis B virus in hospital, the present finding disagrees with a study done in Northern Vietnam [14] half (48.2\%) of the participants reported they routinely recapped the used needles with two hands after injection, putting them at greater risk of needle stick injury. The numbers of participant attended training concerning hepatitis (13.2\%) it disagrees with findings obtains from another study that mentioned the majority of the study sample was trained (80\%) [15].The knowledge of the HCPs on HBV detected in semen, or saliva test was moderate compared with the study was done by [16] has good knowledge of the HBV found in semen or saliva test among healthcare workers of Bahir dar city administration. Studies have shown that HBV can be transmitted through the sexual route [17][18], these findings agree with the present study with high knowledge modes of transmission of HBV. An important risk for blood-borne viral spread in some studies carried out around the world was Razor sharing and shaving at barbershops have been identified. More so, razor sharing and shaving from barbershops have been identified as a risk factor for HBV the present study showed the participants had moderate knowledge about hepatitis B transmitted from scissors and blade razors through salon and barbershops, these results disagree with another study in Kumasi, Ghana showed that Knowledge and occupational hazards of barbers in the transmission of hepatitis B and C was low [19]. The current study noted that the majority of 241(79.5) of HCPs knew that hemodialysis patients are at risk for the Hepatitis B virus which is convenient with the findings of a study conducted in Libyan dialysis centers by [20]. Where reported patients with maintenance hemodialysis were at high risk for hepatitis B virus infection than the general population, in some countries, this infection has been controlled in dialysis centers by adherence to hemodialysis-specific infection-control measures to prevent nosocomial transmission and to hepatitis $\mathrm{B}$ vaccination. Nevertheless, HBV infection outbreaks are still seen when failures in infection control procedures occur. Many people with 
a hepatitis B virus infection do not know they are infected since they do not feel or look sick. However, they can still spread the virus to others [21], this report comes along with the current study revealed that three-quarters of the HCPs correctly responded that hepatitis B virus transmitted the disease to another person even Asymptomatic cause with chronic hepatitis B. Incorrectly identified routes of transmission by the respondents include sharing the mouthpiece during a hookah the current finding is however at variance with another a study was done by [22] reported that sharing the mouthpiece during hookah group smoking was a probable source of transmission of pathogens such as viruses, bacteria, and fungi. For instance, a study reported a potential risk for transmission of communicable diseases such as hepatitis $\mathrm{C}$ when sharing the mouthpiece between users with gingivitis or any other type of lesion in the oral cavity makes them likely to transmit or be infected. The majority of the HCPs knew about the transmission of HBV to the infant at the time of birth as a result of exposure to maternal cervical secretions and maternal blood that contain the virus, the current study agrees with the study done by [23] on the hepatitis B Virus Infection during Pregnancy: Transmission and Prevention. The current study showed that most of the HCPs had moderate knowledge of possible risk and mode of disease transmission. However knowledge about preventive aspect was found high, the study conducted in Karachi reported similar findings of knowledge, attitude, and practice of hepatitis B and C, which showed that most of the HCPs had enough knowledge of possible risk and mode of disease transmission [24]. Whereas a statistically significant difference was found between the educational level and HCPs knowledge regarding hepatitis B, this finding is, however, at variance with another study done in Karachi (Pakistan) where the respondents demonstrated a very low knowledge of hepatitis B.

\section{CONCLUSION}

Most of the healthcare professionals in the study sample had a moderate level of knowledge regarding the hepatitis $\mathrm{B}$ virus. Also, the current study demonstrated a significant association between the educational level and HCP's knowledge regarding $\mathrm{HBV}$, at $\mathrm{P}$ value less than (0.05). On the other hand, there was no significant association between HCP's age, gender, marital status, years of employment, and training course concerning hepatitis B with the level of knowledge regarding HBV. The researcher recommended that the training course must be designed by the ministry of health/infection control department for theater HCPs staff to provide appropriate performance HCPs updating because of changing knowledge and practices. The theater healthcare professional's staff should be given more appropriate to attend symposia regarding infection control the member of HCPs should train on hepatitis.

\section{REFERENCE}

[1] M. Aniji, N. Kavitha, S. Balamuralitharan, "Approximate solutions for HBV infection with stability analysis using LHAM during antiviral therapy,” Bound Value Probl, pp. 80, 2020.

[2] WHO, "hepatitis," Abril. 31, 2020 [Online]. Available: https://www.who.int/news-room/factsheets/detail/hepatitisb\#: :text=Hepatitis $\% 20 \mathrm{~B} \% 20 \mathrm{is} \% 20 \mathrm{a} \% 20$ potentially, from $\% 20$ cirrhosis $\% 20$ and $\% 20$ live r\%20cancer. [Accessed: Sept. 12, 2020]. (General Internet site)

[3] S. Gupta, "Studies on hepatitis viruses: life cycle, structure, functions, and inhibition," London: Elsevier/Academic Press, 2018.

[4] D. Moralejo, R. El Dib, R. Prata, P. Barretti, I. Corrêa, "Improving adherence to Standard Precautions for the control of health care-associated infections," Cochrane Database of Systematic Reviews, 2018.

[5] Federal Bureau of Prisons Clinical Practice Guidelines, "Medical Management of Exposures: HIV, HBV, HCV, Human Bites, and Sexual Assaults," 2014.

[6] A. Pruss-Ustun, E. Rapiti, Y. Hutin, "Sharps injuries: Global burden of disease from sharps injuries to healthcare workers," 2014.

[7] G. Abeje, M. Azage, "Hepatitis B vaccine knowledge and vaccination status among health care workers of Bahir Dar City Administration, Northwest Ethiopia: a cross sectional study,” BMC infectious diseases, 15(1), pp.30, 2015.

[8] S. Shah, N. Nisar, M. Qadri, "Knowledge regarding Hepatitis-B among EPI vaccinators working in District South, Karachi,” PAKISTAN JOURNAL OF MEDICAL SCIENCES, 23(4), pp.538, 2007. 
[9] S. Samuel, S. Aderibigbe, T. Salami, O. Babatunde, "Health workers' knowledge, attitude and behaviour towards hepatitis B infection in Southern Nigeria," International Journal of Medicine and Medical Sciences, 1(10), pp.418-424,2009.

[10] World Health Organization, "Hepatitis B Fact Sheet N: 204," Geneva 2000. [Online]. Available: $\mathrm{http} / /$ :www.who.intmediacentre/factsheet/ fs204/en/2000. [Accessed: Sept. 12, 2000]. (General Internet site)

[11] R. Elizabeth, U. Ross, "The ethics of infection prevention among health care workers. Canadian Med," Asso. J., 164(10), pp. 1447-1448, 2001.

[12] S. Setia, R. Gambhir, V. Kapoor, G. Jindal, S. Garg, "Attitudes and Awareness Regarding Hepatitis B and Hepatitis C Amongst Health. Care Workers of a Tertiary Hospital in India," Annals of medical and health sciences research, 3(3), pp.551-558, 2013.

[13] R. Yacoub, R. Al Ali, G. Moukeh, A. Lahdo, Y. Mouhammad, M. Nasser, "Hepatitis B vaccination status and needlestick injuries among healthcare workers in Syria," Journal of global infectious diseases, 2(1), pp. 28, 2010.

[14] T. Hang Pham, T. Le, D. Nguyen, C. Luu, B. Truong, P. Tran, et al., "Knowledge, attitudes and medical practice regarding hepatitis B prevention and management among healthcare workers in Northern Vietnam," PloS one, 14(10), pp. e0223733, 2019.

[15] C. Gajana, M. Gauta, "Study Of Knowledge, Attitude And Practices Of Universal Precautions Among Health Care Workers In Rural Hospital Delhi," International-Journal-Of-Scientific-Research, 6(6), 2017.

[16] G. Abeje, M. Azage, "Hepatitis B vaccine knowledge and vaccination status among health care workers of Bahir Dar City Administration, Northwest Ethiopia: a cross sectional study," BMC infectious diseases, 15(1), pp. 30, 2015.

[17] A. Kabir, S. Tabatabaei, S. Khaleghi, S. Agah, , A. Kashani, M. Moghimi, , et al., "Knowledge, attitudes and practice of Iranian medical specialists regarding hepatitis B and C," Hepatitis monthly, 10(3), pp.176, 2010.

[18] A. Jimenez, N. El-Din, M. El-Hoseiny, M. El-Daly, M. Abdel-Hamid, S. El Aidi, "Community transmission of hepatitis B virus in Egypt: results from a case-control study in Greater Cairo," International journal of epidemiology, 38(3), pp.757-765, 2009.

[19] M. Mutocheluh, K. Kwarteng, "Knowledge and occupational hazards of barbers in the transmission of hepatitis B and C was low in Kumasi, Ghana," The Pan African Medical Journal, pp. 20, 2015.

[20] W. Alashek, C. McIntyre, M. Taal, "Hepatitis B and C infection in haemodialysis patients in Libya: prevalence, incidence and risk factors," BMC infectious diseases, 12(1), pp.265, 2012.

[21] CDC, "Hepatitis B Information - FAQs," Statistics, Data and Guidelines, 2020.

[22] H. Qasim, A. Alarabi, K. Alzoubi, "The effects of hookah/waterpipe smoking on general health and the cardiovascular system," Environ Health Prev Med, 24, pp. 58, 2019.

[23] B. Navabakhsh, N. Mehrabi, A. Estakhri, M. Mohamadnejad, H. Poustchi, "Hepatitis B Virus Infection during Pregnancy: Transmission and Prevention," Middle East journal of digestive diseases, 3(2), pp. 92-102, 2011.

[24] S. Shah, N. Nisar, M. Qadri, "Knowledge regarding Hepatitis-B among EPI vaccinators working in District South, Karachi,” PAKISTAN JOURNAL OF MEDICAL SCIENCES, 23(4), pp.538, 2007.

Kurdistan Journal of Applied Research $\mid 4^{\text {th }}$ International Conference on the Health and Medical Science: Medical Researches Improve Life Quality (ICHMS 2020) | 186 